Portland State University

PDXScholar

$5-15-1978$

\title{
A Consumer Evaluation of the Clackamas County Family Court Service
}

\author{
Barbara E. Lee \\ Portland State University \\ Patricia E. Watne \\ Portland State University
}

Follow this and additional works at: https://pdxscholar.library.pdx.edu/open_access_etds

Part of the Counseling Commons, and the Social Work Commons Let us know how access to this document benefits you.

\section{Recommended Citation}

Lee, Barbara E. and Watne, Patricia E., "A Consumer Evaluation of the Clackamas County Family Court Service" (1978). Dissertations and Theses. Paper 2807.

https://doi.org/10.15760/etd.2802

This Thesis is brought to you for free and open access. It has been accepted for inclusion in Dissertations and Theses by an authorized administrator of PDXScholar. Please contact us if we can make this document more accessible: pdxscholar@pdx.edu. 


\section{ABSTRACT}

This report describes a consumer evaluation study of the Clackamas County Family Court Service, a court-connected marriage and divorce counseling agency near Portland, Oregon.

A questionnaire was mailed to 168 individuals who had participated in counseling at the agency between November 1, 1976, and November 1, 1977. The questionnaire focused on former clients' perspectives on agency helpfulness, satisfaction with counselor's assistance, accomplishment of agency identified objectives for counseling, and suggested areas for program improvement.

A majority of respondents indicated that agency involvement had been helpful and that counselor assistance had been satisfactory. Almost half of the participants offered a suggestion for improvement of the agency. Members of couples who participated in counseling did not significantly differ in their perceptions of agency involvement.

The relationship between respondents' characteristics taken from case record data and their responses on the questionnaire was examined. Through multiple regression analyses, it was found that the number of sessions attended affected client satisfaction more than any other characteristic. Clients who stated that the number of sessions attended was about right also indicated a higher level of satisfaction with the agency.

Respondents and nonrespondents differed in two characteristics. Respondents were slightly older and were less likely to have been 
involved in divorce proceedings at the time of counseling than nonrespondents. However, a sample survey of nonrespondents indicated that respondents and nonrespondents had similar opinions on selected questionnaire items. 


\title{
A CONSUMER EVALUATION OF THE CLACKAMAS \\ COUNTY FAMILY COURT SERVICE
}

$$
\text { by }
$$

BARBARA E. LEE and PATRICIA E. WATNE

A research practicum submitted in partial fulfillment of the requirements for the degree of

\author{
MASTER OF SOCIAL WORK
}

Portland State University

1978 
TO THE OFFICE OF GRADUATE STUDIES AND RESEARCH:

The Advisor approves the practicum of Barbara E. Lee and Patricia E. Watne presented May 15, 1978.






\section{ACKNOWLEDGEMENTS}

The authors of this report would like to thank the following persons for their assistance: Nancy Koroloff, Susan Hines, and Quentin D. Clarkson of the Regional Research Institute for Human Services; and F. Nolan Jones, Stanley Cohen, and the staff of the Clackamas County Family Court Service. 
TABLE OF CONTENTS

PAGE

ACKNOWLEDGEMENTS .............................

LIST OF TABLES .................................. vii

CHAPTER

I STATEMENT OF THE PROBLEM ............... 1

Introduction: Purposes of the Study . . . . . 1

Definitions of Terms ........... 2

Overview of the Family Court System . . . . . 2

Description of the Clackamas County Family

Court Service ........... 4

Agency Conceptual Model for Counseling . . . . 6

II LITERATURE REVIEW . . . . . . . . . . . 8

Overview of Consumer Evaluation of Family

Court Programs ........... 8

Maricopa County Conciliation Court Service . . . 9

Multnomah County Conciliation Court Service . . . 10

Los Angeles County Conciliation Court . . . . . 11

Hennepin County Court Services Divorce

Experience Program ......... 12

Wayne County Circuit Court Marriage

Counseling Service......... 13

Implications of Previous Consumer Evaluation

Surveys for This Study......... 14 
III METHODOLOGY . . . . . . . . . . . . . . . . . 19

Evaluation Model ............ 19

Specify Program Goals and Objectives...... 20

Establish Criteria for Program Success . . . . . 21

Determine Design for the Evaluation and Develop Data Gathering Instruments ..... 22

Collect Data............... 26

IV DATA ANALYSIS ......................... 29

Characteristics of the Study Sample . . . . 29

Analysis of the Differences in Characteristics between Respondents and Nonrespondents ... 33

Responses to the Mail-Out Questionnaire .... 35

Analysis of the Responses to the Telephone Survey of a Sample of Nonrespondents . . . . 42

Analysis of Couples' Perceptions of the Agency . .

Analysis of Correlation between Clients' Perceptions of Agency Helpfulness and

Satisfaction with Counselor's Assistance...

Analysis of the Relationship between Characteristics of the Respondents and Their

Responses on the Questionnaire ...... 45

$\checkmark$ IMPLICATIONS AND RECOMMENDATIONS . . . . . . . . 51

Questionnaire Results and Implications

for the Family Court Service....... .

Questionnaire Response Rate and Implications

for the Family Court Service ...... . 56

Critique of the Evaluation Process, Study

Sample, and Questionnaire ........ 
CHAPTER

PAGE

V (continued)

Recommendations for the Development of an Ongoing Consumer Evaluation System . . . 63

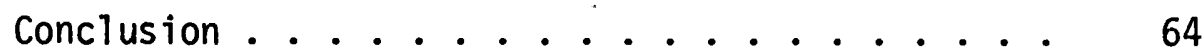

SELECTED BIBLIOGRAPHY • . . . . . . . . . . . . . . . . 66

APPENDIXES : . . . . . . . . . . . . . . . . . 69 


\section{LIST OF TABLES}

TABLE

PAGE

1 Characteristics of the Sample ...........

2 Differences in Characteristics between Respondents

and Nonrespondents .............

3 Clients' Perceptions of Agency Helpfulness or

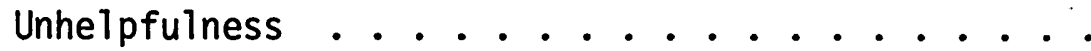

4 Ways in Which Clients Saw Agency to Be Helpful or Unhelpfut . . . . . . . . . . . 36

5 Clients' Perceptions of Agency Helpfulness in

Learning Cooperative Parenting Skills . . . . .

6 Clients' Perceptions of Agency Helpfulness in

Learning Conflict Management . . . . . . . .

7 Clients' Perceptions of Agency Helpfulness in

Learning to Help Children Adjust to Family

Problems, Separation, or Divorce ........

8 Clients' Perceptions Regarding Satisfaction with

Counselor's Assistance . . . . . . . . .

9 Ways in Which Clients Were Satisfied or Dissatisfied with Counselor's Assistance ..........

10 Clients' Opinions Regarding the Number of Sessions

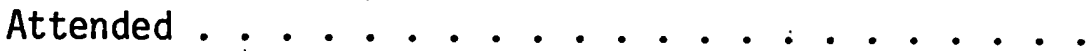


11 Clients' Suggestions for Changing or Improving the Agency ............... . . 41

12 Additional Services Suggested by Clients . . . . . . 42

13 Estimated Sample Bias from a Telephone Survey of

Nonrespondents .............. . . . 43 43

14 Analysis of Relationship between Clients'

Characteristics and Learning How to Better

Handle Differences with Spouse or Ex-spouse ....

15 Analysis of Relationship between Clients'

Characteristics and Satisfaction with

Counselor's Assistance . . . . . . . ...

16 Analysis of Relationship between Clients'

Characteristics and Whether or Not They

Found the Family Court Service Helpful . . . . . . 
CHAPTER I

\section{STATEMENT OF THE PROBLEM}

This chapter presents an introduction to the purposes of the study, definitions of terms used in this report, an overview of the family court system, and a description of the Clackamas County Family Court Service and its conceptual model for counseling.

\section{SECTION 1, INTRODUCTION: PURPOSES OF THE STUDY}

Consumer feedback is becoming an increasingly important tool for the evaluation of social services programs. The consumer movement of the last decade and the growth of the program evaluation field have contributed to new efforts in the development and expansion of consumer evaluation research in social agencies.

This report describes a consumer evaluation project conducted from October 1977 to May 1978 at the Clackamas County Family Court Service, a court-connected marriage and divorce counseling agency. The purposes of this project were threefold. They were to:

(1) Provide a pilot study to aid in the development of an ongoing consumer feedback system at the Family Court Service

(2) Provide data regarding former clients' perspectives on agency service 
(3) Discuss the process of consumer evaluation planning and execution to assist other family court programs in the development of consumer feedback systems

\section{SECTION 2, DEFINITIONS OF TERMS}

For the purposes of this report, the following definitions of terms are used:

Evaluation: A process of making reasonable judgments about program performance based on systematic data collection and analysis.1

Consumer evaluation, consumer feedback: Evaluation of a program, or part of a program, by the clients or former clients of the service.

Goal: The broad intention(s) of a program. ${ }^{2}$

Objective: A measurable standard of behavior related to an identified goal. 3

Criterion: What is considered to be a desirable level of accomplishment or competency in performing an identified behavior. 4

\section{SECTION 3, OVERVIEW OF THE FAMILY COURT SYSTEM}

Clackamas County Family Court Service (hereafter referred to as the Family Court Service) is one of five programs in Oregon offering

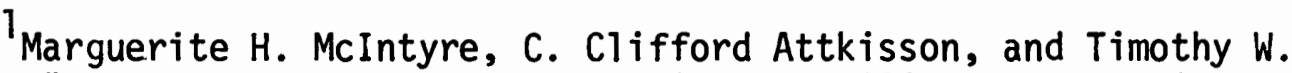
Keller, "Components of Program Evaluation Capability in Community Mental Heal th Centers," in Resource Materials for Community Mental Heal th Program Evaluation, ed. William A. Hargreaves, C. Clifford Attkisson, and James E. Sorenson (Washington, D.C.: Government Printing Office, 1977), p. 9.

2 Quentin D. Clarkson, Nancy Koroloff, and Wayne Neuburger, "The Evaluation Process," in Readings in Program Evaluation (Portland, Ore.: Regional Research Institute for Human Services, Portland State University, 1977), p. 6. 
court-connected marriage and divorce counseling. Few in number prior to ten or fifteen years ago, family court programs are now available in many parts of the country to assist the growing number of people involved in marital disruption and divorce. ${ }^{5}$ The family court system has its own professional organization, The Association of Conciliation Courts, and journal, Conciliation Courts Review (established in 1963).

Family court service programs range from court-administered, mandatory counseling for divorcing parents of minor children, to independently administered, voluntary marriage and divorce counseling. 6

Until recently, reconciliation of disrupted or divorcing couples was probably a chief goal of most family court service counseling programs. ${ }^{7}$ There are now indications that the counseling goal of reconciliation is increasingly being replaced by the goal of facilitation of positive couple and parental relationships with or without divorce. 8 (Chapter II, Section 6 of this report discusses this issue in greater detai1.)

5 Meyer Elkin, "Conciliation Courts: The Reintegration of Disintegrating Families," The Family Coordinator 22 (January 1973):63-64.

6 Prudence Brown and Roger Manela, "Client Satisfaction with Marital and Divorce Counseling," The Family Coordinator 26 (July 1977): 294.

7 Emily H. Brown, "Divorce Counseling," in Treating Relationships, ed. David 01 son (Lake Mị1s, Iowa: Graphic Publishing Co., 1976), p. 407.

8 Brown and Manela, "Client Satisfaction," p. 295; and Kenneth Kressel et al., "Professional Intervention in Divorce: A Summary of the Views of Lawyers, Psychotherapists, and Clergy," p. 57. (Mimeographed.) 


\section{SECTION 4, DESCRIPTION OF THE CLACKAMAS}

COUNTY FAMILY COURT SERVICE

The Family Court Service is a small marriage and divorce counseling agency serving a suburban and rural county bordering the city of Portland, Oregon. Clackamas County is a rapidly growing area with a current approximate population of 210,000 people. It is comprised of scantly populated farming and wooded sections as well as suburban communities and small cities. The county ranks high among counties in the state in median family income (estimated from 1976 figures at $\$ 15,560$ / year). In 1975, there were 1,184 divorces in the county, a rate of 5.8 per 1,000 population. 9

The Family Court Service was established in 1976 by the county Circuit Court in response to a study that indicated the need for a public divorce counseling agency. F. Nolan Jones and Stanley Cohen, the directors of this study, entitled The Impact of Divorce on Children and Parents (1975-1976), articulated the general goal and objectives of the new agency. The goal was to "provide short term individual/conjoint 10 and group counseling to couples contemplating and/or involved in divorce proceedings." General program objectives included helping parents to constructively resolve custody, visitation, and child support issues, assisting in the development of cooperative parental relationships in marriage or divorce, providing advocacy for children of disrupted or

${ }^{9}$ Clackamas County Community Action Agency, "Clackamas County Profile Sheet," p. 1.

${ }^{10}$ The term conjoint is here used to signify counseling with a couple, rather than an individual. 
divorcing families, and, when appropriate, facilitating the avoidance of unnecessary divorces. This statement of agency purpose and objectives was supported by the Clackamas County Circuit Court, the local Bar Ássociation, and the agency's Board of Advisors.

Family court agencies in Oregon are organized under 1965 state legislation which allows counties to establish and maintain courtconnected conciliation services. ${ }^{11}$ State legislation in 1975 allowed counties to add an additional $\$ 35$ fee to all divorce petition filings to help subsidize family court programs. In Clackamas County, agency clients who have not paid this amount are charged a $\$ 35$ total fee for services. For other clients, there are no additional charges for agency services. 12

While formally part of the Clackamas County Circuit Court, the Family Court Service is independently administered, and does not provide recommendations nor reports (such as custody investigations) to the court. Counseling is confidential, and agency staff may not be subpoenaed to testify in court regarding cases.

Client involvement with the service is for the most part voluntary, with the majority of referrals provided by attorneys, and the remainder by judges, doctors, mental health professionals, friends and relatives, and self-referral. Clackamas County families are eligible for service before or after a divorce, or during the period of divorce

${ }^{11}$ See Oregon Domestic Relations Statutes 107.510 through 107.610.

12 Family court agencies in Oregon differ in their fee assessment policies. Certain services in the state do not charge a fee to those clients who have not filed a divorce petition. 
proceedings. Families including minor children receive priority service.

Generally, one staff counselor is assigned per case. A shortterm, one- to eight-session counseling model is used. An effort is made to include both parents in counseling, and children are at times invited to participate in sessions. The Family Court Service does not use the counseling petition method utilized by some family court agencies and provided for by state statute. ${ }^{13}$ This method involves couples signing a petition, or contract, which binds them to a counseling series and delays any legal divorce actions.

Agency staff is composed of a director, two support services staff, two part-time consultants, and five graduate students in social work and counseling.

\section{SECTION 5, AGENCY CONCEPTUAL MOBEL FOR COUNSELING}

The Family Court Service conceptual model for counseling might be summarized as follows:

(1) Client involvement in identification of problems, goal setting, and decision making are believed to be important parts of the counseling process.

(2) Marital and parental conflicts are seen as natural, and to some extent, inevitable. Familial conflicts may be successfully managed, but are rarely (unless one party leaves) permanently resolved.

${ }^{13}$ See Oregon Domestic Relations Statutes 107.550 through 107.570. 
(3) Individual and family problems are viewed as social, as well as personal in nature. It is frequently not successful to address problems solely at the individual lever.

(4) It is believed that successful counseling requires the participation, when possible, of all involved family members. A combination of individual and couple counseling, and when appropriate, family counseling, is most likely to be beneficial.

(5) It is believed that marital and parental problems, while frequently related, may often be addressed separately in counseling. Thus, termination of a marriage does not necessarily prevent counseling to develop a cooperative parental relationship.

(6) Staff involvement in decision making related to the execution and improvement of the agency counseling program is viewed as important.

Chapter II, Section 6 of this report discusses the implications of this conceptual model for the development of a consumer feedback instrument. 
CHAPTER II

\section{LITERATURE REVIEW}

This chapter examines consumer feedback studies of several family court service programs, and discusses implications for consumer evaluation of the Clackamas County Family Court Service.

\section{SECTION 1, OVERVIEW OF CONSUMER EVALUATION OF FAMILY COURT PROGRAMS}

There is a growing amount of research being conducted in the field of marriage and divorce counseling, and personal and family adjustment to divorce. However, there are few available consumer evaluation studies of family court service programs.

An informal survey of three Oregon family court agencies ${ }^{1}$ revealed that although each had collected some consumer feedback information in the past, or was planning such collection in the future, no comprehensive system of consumer evaluation was being executed in any of the services at the time. The Clackamas County Family Court Service had conducted no consumer feedback project prior to the study described in this report. (As mentioned, the agency has been in operation only since 1976).

The following sections of this chapter discuss five court service consumer evaluation projects completed in the years 1971 to 1976 at

${ }^{1}$ of the five court services in Oregon, three were contacted by telephone in August 1977 by the authors of this report. 
agencies in Arizona, Oregon, California, Minnesota, and Michigan. Project design and variables under examination are here discussed for each study. Some findings of the studies and response rates are discussed in Chapter $V$ of this report.

\section{SECTION 2, MARICOPA COUNTY CONCILIATION COURT SERVICE}

Furman et al. ${ }^{2}$ conducted a consumer evaluation study of the Maricopa County (Phoenix, Arizona) Conciliation Court Service. This service was described as offering short-term counseling to couples seeking to avoid marital disruption or divorce. A counseling petition system (using a written reconciliation agreement) was available to individuals on a voluntary basis. If one partner chose to sign the reconciliation agreement, participation in counseling became mandatory for both partners.

A sample of one hundred married couples (two hundred individuals) was chosen for the study. This group represented the approximate number of cases completed at the agency during a one-month period. The sample was selected from former clients who had completed a series of counseling sessions within three months of the study.

Data were collected by means of a mail-out questionnaire. Participants were asked if they would recommend the service to a friend, if counseling had helped them to reach a satisfactory decision, and if they felt free to express themselves in counseling. Questions were also

2 Glenn Furman et al., "Clients' Perceptions of Conciliation Court Services" (Masters research project, Arizona State University, 1971). 
included regarding opinion of the number of sessions, current relations with spouse, reconciliation status, expectations of counseling, the role of the counselor, and whether marital problems had been, brought out clearly during counseling.

SECTION 3, MULTNOMAH COUNTY CONCILIATION COURT SERVICE

Dudley et al. ${ }^{3}$ conducted a consumer feedback study of the Multnomah County (Portland, Oregon) Conciliation Court Service. The study described this agency as offering short-term marriage and divorce counseling to couples in the process of divorce or before divorce. A counseling petition system (similar to that available in the Maricopa County Conciliation Court Service) was used. Under this system, counseling was initiated by one partner seeking help and signing a reconciliation petition. At this point, an interview with a counselor became mandatory for both partners.

The Multnomah County consumer evaluation instrument consisted of a very short, self-administered questionnaire printed on a mail-back postcard. A sample of approximately 20 percent of the agency's clientele during the past year was drawn (using a serial method). This group consisted of 134 couples (268 individuals).

The following items were included on the questionnaire: referral source, number of sessions each partner attended, reconciliation status, feelings regarding using the agency again, length of court hearing

3 James E. Dudley et al., "Testing of a Design for Client Evaluation of a Conciliation Service". (Masters practicum, Portland State University, 1972). 
if divorced, and willingness to recommend the agency to a friend.

\section{SECTION 4, LOS ANGELES COUNTY CONCILIATION COURT}

The Los Angeles County Conciliation Court was one of the earliest family court services, and has established many precedents in the field of court-connected divorce counseling. ${ }^{4}$

There is no available report that gives a detailed account of consumer feedback data collection at the Los Angeles County service. However, Elkin ${ }^{5}$ described the collection of information regarding the reconciliation status of former agency clients.

According to Elkin, the service offered short-term counseling to couples considering divorce or involved in divorce. A counseling petition system was used in which the individual seeking help completed a check list of marital problems and a request for counseling. Both partners were then obligated to attend counseling sessions.

Follow-up information on the reconciliation status of former clients was routinely collected by the agency. Information is not available regarding the method of data collection, whether information was requested from all previous clients or a sample, or whether other follow-up information was also obtained.

${ }^{4}$ Elkin, "Counciliation Courts," and "Short-Contract Counseling in a Conciliation Court," Social Casework 43. (April 1962):184-190.

$5^{5}$ Elkin, "Conciliation Courts," p. 65. 


\section{SECTION 5, HENNEPIN COUNTY COURT SERVICES} DIVORCE EXPERIENCE PROGRAM

Rhodes and Ihlow ${ }^{6}$ conducted a consumer feedback study of the Hennepin County (Minneapolis, Minnesota) Court Services Divorce Experience Program. The Divorce Experience Program was described as a monthly series of three weekly educational group sessions on the personal experience of divorce, legal concerns and the emotional process of the adult divorce experience, and children's emotional experience with divorce. The sessions consisted of a presentation to the audience and small group discussions. Participation in the program was voluntary, and most attendees were separated or divorced and were not accompanied by a spouse. Consumer feedback was collected for one month's program by means of a self-administered questionnaire distributed to the audience at the conclusion of each week's session. Thus, the study sample consisted of the sixty-six separate individuals who attended at least one session and completed a questionnaire.

The questionnaire asked participants to indicate to what degree the evening's presentation had met their needs in that particular area, and to what degree the small group discussion had been helpful. Individuals were also asked to indicate the way in which the discussion had been helpful. Other items included on the instrument were identification of the most helpful part of the session, willingness to recommend the program to a divorcing person, and identification of anything especially disliked about the program

${ }^{6} \mathrm{Clifton}$ A. Rhodes and Ginger Ihlow, "Evaluation Findings on the Divorce Experience Program, October, 1975," Hennepin County Court Service, 1975. (Mimeographed.) 


\section{SECTION 6, WAYNE COUNTY CIRCUIT COURT}

MARRIAGE COUNSELING SERVICE

Brown ${ }^{7}$ examined client satisfaction with the Wayne County (Detroit, Michigan) Marriage Counseling Service as one aspect of a study of psychological distress and personal growth among women in the process of divorce.

The Marriage Counseling Service was described as offering voluntary, confidential marriage and divorce counseling independent from the lega1 process. Six hundred fifty-nine former and current clients were selected for structured interviews at first contact with the service, and at a point four months later. A large majority of the sample were individuals involved in divorce, although one-half of the women and three-quarters of the men indicated that they did not wish to be divorced. Sixty percent of the study participants had attended counseling with their spouse. A significant proportion of the sample was still involved in counseling at the agency at the time of the study.

Client satisfaction with the Marriage Counseling Service was the topic of two interview questions. Consumers were asked to what degree they had found agency involvement helpful or unhelpful. They were then asked to comment on the ways in which the agency had helped or failed to help.

7 Brown and Manela, "Client Satisfaction"; and Prudence Brown, "Psychological Distress and Personal Growth among Women Coping with Marital Dissolution" (Ph.D. dissertation, The University of Michigan, 1976). 


\section{SECTION 7, IMPLICATIONS OF PREVIOUS CONSUMER}

EVALUATION SURVEYS FOR THIS STUDY

The five previously described consumer feedback projects have several implications for the Clackamas County Family Court Service consumer evaluation study. These implications are in the areas of staff involvement in evaluation planning, type of feedback gathered from consumers, study findings, and response rates. The first two areas are discussed in the following paragraphs. The issues of study findings and response rates are discussed in this report's final chapter.

Chapter I, Section 5 of this report states that an important part of the Family Court Service counseling model is staff involvement in decision making related to the program. The Los Angeles, Hennepin, and Wayne County studies did not mention the use of staff input in evaluation planning. The Multnomah County study cited staff involvement in questionnaire construction, and the Maricopa County. study described a staff review of the instrument.

Clarkson et al. cite staff involvement in evaluation planning, particularly in the areas of goal identification and prioritization, as a means to increase staff cooperation with the study as well as heighten the usefulness of the data collected to the workers. 8 Further, staff participation in the study planning may increase the appropriateness of any program revisions contemplated as a result of study findings. (In Chapter III of this report, Sections 3-7 include discussions of how

${ }^{8}$ Clarkson, Koroloff, and Neuburger, "Evaluation Process," p. 6. 
staff involvement was used in the Family Court Service consumer feedback study. In Chapter $V$, agency use of study findings is discussed.)

The five described consumer feedback studies examined a range of variables related to divorcing couples and families. It may be assumed that these variables were viewed by the evaluators as highly significant in relation to the counseling programs of the involved agencies. An examination of the Family Court Service conceptual model for counseling suggests some differences in variables of significance for this program.

First, the Clackamas County model dictates that counseling may be useful regardless of whether or not clients divorce. Thus, the reconciliation rate for couples is not an appropriate measure of program success. Brown ${ }^{9}$ described reconciliation status as a traditionally used indication of divorce counseling success, and this view is strongly reflected in the cited studies in Maricopa, Los Angeles, and Multnomah County. In each of these studies, reconciliation status was a key variable under examination.

In recent years, emphasis on the reconciliation factor may have been lessening. ${ }^{10}$ For example, the Wayne County study did not focus on the reconciliation status of sample individuals. A host of factors may be responsible for this apparent trend, including society's increasing acceptance of divorce, greater numbers of divorced individuals, and the broadened scope of family court service programs.

9Brown, "Divorce Counseling," p. 407.

10 Kressel et a1., "Professional Intervention," p. 57. 
Second, the Family Court Service program emphasizes client involvement in identification of problems and goal setting. Thus, program success must be measured not just in terms of agency or counselor identified objectives, but also in terms of client identified objectives for counseling. The Wayne County and Maricopa County studies each used open-ended questions to assess clients' expectations or perceptions of the usefulness of agency involvement. In the Hennepin County study, participants were asked to choose among several responses regarding the helpfulness of the program, but apparently were not asked an open-ended question in this area. Similarly, the Multnomah County study did not solicit open comments regarding agency helpfulness. Due to the briefness of the description of the Los. Angeles study, it is not clear what (if any) question was asked regarding clients' perceptions of agency helpfulness.

Third, the Family Court Service program focuses not just on the individual, but on the entire family involved in marital disruption or divorce. Thus, program success is measurable only in terms of helpfulness to all involved family members. The Minneapolis study emphasized the impact of the Divorce Experience Program on involved individuals, but not on couples or families. In the Maricopa County study, the instrument used had items focusing on the impact of counseling on couples as well as on individuals. For example, participants were asked if counseling had resulted in a change of feelings toward their spouse. The Multnomah County study included two items concerning the effects of counseling on couples, reconciliation status, and length of court hearing if divorced. A short court hearing was used as a possible 
indication of skills in divorce problem solving by couples. In the Wayne County study, consumer feedback questions were directed at the individual's perception of agency usefulness. It is not clear whether the Los Angeles study solicited information other than the reconciliation status of couples.

Finally, part of the Family Court Service's conceptual model for counseling is the belief that marital and parental conflicts may be successfully managed, but are rarely permanently solved. As described by Sprey, family life consists of a complex series of interpersonal negotiations, 11 and "separation is indeed the one and only way to settle conflict for once and for all . . "12 Thus, consumer feedback should be collected regarding learning in the area of conflict management, rather than achieving the resolution or disappearance of problems. In the Maricopa County study, participants were asked whether counseling had resulted in a lessening of marital conflict. This question seems to reflect a conflict resolution, rather than a conflict management stance. As previously mentioned, the Maricopa, Multnomah, and Los Angeles County studies each emphasized reconciliation status as a measure of program success. It is not apparent whether the variable of reconciliation status was viewed as an indication of couples' learning regarding conflict management, or as an indication of successful conflict resolution (i.e., couples who reconciled resolved certain conflicts

11 Jetse Sprey, "On the Management of Conflict in Families," Journal of Marriage and the Family 33 (November 1971):725.

12 Jetse Sprey, "The Family as a System in Conflict," Journal of Marriage and the Family 31 (November 1969):0706. 
while unreconciled couples did not). As mentioned, the Family Court Service program emphasizes that successful conflict management may occur even when couples divorce, especially in the area of cooperative parenting.

In summary, the five studies have several implications for a consumer feedback study of the Family Court Service. The need for further research in consumer evaluation of court service agencies is indicated by the small number of previous studies, and by the diverse and changing nature of divorce counseling programs. 


\section{CHAPTER III}

\section{METHODOLOGY}

This chapter discusses evaluation planning and data collection for the Family Court Service consumer feedback study. In evaluation planning, the topics of specification of program goals and objectives, establishment of criteria, and determination of study design and development of data gathering instruments are addressed.

\section{SECTION 1, EVALUATION MODEL}

The model chosen for this evaluation study was as follows:

Evaluation Process: 1

I. Specify program goals and objectives

II. Establish criteria for program success

III. Determine design for the evaluation and develop data gathering instruments

IV. Collect data

V. Analyze data

VI. Determine course of action

The following sections of this chapter discuss the implementation of the first four steps of the evaluation process. Step $V$ is the subject

${ }^{1}$ Adapted from Clarkson, Koroloff, and Neuburger, "Evaluation Process," p. 3. 
of Chapter IV of this report and Step VI is addressed in the fifth and final chapter.

\section{SECTION 2, SPECIFY PROGRAM GOALS AND OBJECTIVES}

The first step in the evaluation process was to specify the goals and objectives for the program being evaluated. This was necessary in order to develop appropriate instrument(s) for the measurement of program success.

The statement of program goal and objectives discussed in Chapter I, Section 4 of this report was the sole identification of agency purpose from the service's inception in July 1976 until October 1977. During October 1977 a three-hour staff workshop was held to describe agency purpose in detail, and to involve staff members in the process of goal and objective description. Since this consumer evaluation study measured client satisfaction for the previous year of service, the focus of the workshop was the description of agency goals for that period. In addition to providing a base for the development of an evaluation instrument, the workshop aimed to strengthen staff understanding and consensus around agency purpose, and to build an interest in the evaluation process. A11 staff members, including support services personnel, were encouraged to attend.

The workshop began with the staff dividing into two groups in order to facilitate individual contribution to the listing of agency goals. The groups then combined to eliminate duplicates on the goal lists, group the goal's into categories, and prioritize the categories. The remaining time was used to list objectives, introduce the concept of 
criteria setting, and discuss general evaluation issues, such as client confidentiality.

By combining data from the staff workshop with the agency's original statement of purpose, the following list of the priority goal and objectives of the Family Court Service was formulated:

Goal: To provide counseling to Clackamas County families which facilitates the positive adjustment of parents and children to situations before divorce, during divorce, or after divorce.

Objectives:

1. To facilitate the avoidance of unnecessary court actions, including unnecessary divorces and custody and visitation disputes

2. To facilitate cooperative parenting in situations prior to divorce, during divorce, or after divorce

3. To educate families regarding issues such as coping with family stress, helping children adjust to marital disruption or divorce, and managing marital and parental conflicts

4. To facilitate the positive adjustment of children by performing advocacy for children of families in the process of divorce, before divorce, or after divorce

SECTION 3, ESTABLISH CRITERIA FOR PROGRAM SUCCESS

Criteria setting has been described as an important step in the identification of concrete program objectives. According to clarkson et al.: 
Objectives should include

1. A description of the behavior related to the goals

2. How the behavior is to be measured

3. A criterion for successful attainment of the objective ${ }^{2}$ Many social service agencies lack specified criteria related to the achievement of program goals. There are few guidelines in the area of criteria setting, and it is difficult for staff to consider assigning criteria for the success or failure of a counseling program.

The concept of criteria setting was discussed in the Family Court Service workshop on goals and objectives, but no criteria were determined. It is hoped that findings from this consumer feedback study will provide a framework for criteria setting by the agency in the future.

\section{SECTION 4, DETERMINE DESIGN FOR THE EVALUATION} AND DEVELOP. DATA GATHERING INSTRUMENTS

The next step in the evaluation process was the determination of the design for the study and the development of data gathering instrument(s). Decisions in this area were made with the assistance of Family Court Service staff members.

It was decided that consumer feedback would be collected from a one-year sample of former agency clients whose cases were open at some time during the prior year (November 1, 1976 to November 1, 1977). The one-year sample was chosen for the following three reasons. First, the period excluded the first few months of agency functioning (July 1, 1976 to October 31,1976$)$ during which staffing patterns were

${ }^{2}$ Ibid., p. 6. 
significantly, different than in the later months. Second, the period chosen included the most recently closed cases as well as those terminated up to twelve months previously. Thus, response rate and consumer feedback content could be analyzed in terms of length of time since agency involvement. Third, the one-year sample included sufficient individuals to insure a fairly large respondent group.

A mail-out questionnaire was chosen as the chief method of data collection. This method was chosen because agency staff agreed on the desirability of a large study participant group, and lack of time and financial resources precluded the collection of data by means of personal interviews. In addition, use of a self-administered questionnaire permitted comparison of findings with several similar consumer evaluation studies cited in Chapter II of this report.

The individual, rather than the parental couple or the family, was chosen as the primary unit of study. Each individual adult who attended at least one session at the Family Court Service during the time period under study was included in the sample.

With agency staff input, a preliminary questionnaire was developed. It included a majority of multiple choice items due to the assumed ease in answering this type of question. To minimize the possibility that the order of multiple choice options would influence responses, the order of options was varied from question to question. Several open-ended questions were also included to insure the widest possible range of responses. The chosen design for the study included a pre-test of the preliminary instrument and interviews with a random 
sample of nonrespondents to determine the differences (if any) between respondent and nonrespondent attitudes.

The questionnaire focused on the following three areas:

1. The service's impact on clients as measured by agency specified objectives

2. Client satisfaction with counselor performance

3. The service's impact on clients as measured by consumer identified objectives

While the first two areas may be commonly found on consumer feedback instruments, the third topic (the service's impact as measured by consumer identified objectives) is often not included. Giordano points out that

. . the researcher may call on the client to evaluate an agency in terms of how well it is performing important tasks or accomplishing central goals. The goals themselves, however, are generally defined by the professionals of the organization. 3

Giordano recommends client participation in questionnaire construction in order to insure that the items included reflect the consumers' perspective as well as that of the agency.

For this purpose, a sample of ten former clients was selected to be interviewed regarding questionnaire content, and also to pre-test the questionnaire as it had been constructed to date. The sample was chosen by staff members suggesting names of former clients who they believed would be interested in participating in development of the instrument. Individuals were chosen from this list so that cases before divorce, during divorce, and after divorce were represented.

${ }^{3}$ Peggy C. Giordano, "The Client's Perspective in Agency Evaluation," Social Work 22 (January 1977):35. 
Two individuals from the sample of ten were unavailable for personal interviews. Eight individuals--three men and five women--were interviewed; two were before divorce at the time of agency involvement, three were during divorce, and three were post divorce. After input regarding questionnaire content was obtained, the questionnaire pretest was conducted. A rist of interview questions may be found in Appendix A.

Some former clients had difficulty in suggesting items for inclusion on the questionnaire. A different method of data collection (a group workshop, for example) might have resulted in more consumer input regarding questionnaire content.

Following the interviews with former clients and discussion with agency staff, the questionnaire was revised and completed. A copy of the final instrument may be found in Appendix $B$.

Questions regarding the helpfulness of the service, number of sessions, and suggested improvements or different services were intended to provide data regarding the usefulness of the agency according to consumers' goals and objectives. Questions regarding parental cooperation, conflict management between spouses or ex-spouses, and positive adjustment of children were intended to provide data regarding the program's usefulness according to agency specified priority objectives. ${ }^{4}$ The question regarding satisfaction with counselor's assistance was designed

4 It was understood that all aspects of the agency's priority objectives could not be included in one client satisfaction questionnaire. Selection of items was based on importance (as defined by agency staff), clarity, and suitability for inclusion on a self-administered questionnaire for parents. 
to reflect the clients' objectives for service, and also to provide staff counselors with feedback regarding their performances.

\section{SECTION 5, COLLECT DATA}

The next step in the evaluation process was to collect the data. The questionnaire was mailed to the entire study sample, and then sent a second time to those individuals who had not returned responses.

Accompanying the first and second questionnaire mailings were the cover letters to be found in Appendixes $C$ and $D$. Three characteristics of these letters should be noted. First, the concept of consumer input in agency evaluation was introduced and emphasized. Second, it was made clear that participation in the survey was voluntary, and that responses were confidential and would not be identified with names. These points underline the survey's purpose of consumer evaluation rather than, for example, follow-up evalulation of individual clients by the agency. Third, signature of the cover letters by the agency's director was chosen instead of a possible signature by a Circuit Court Judge or by the researchers. Cover letter signature may have affected survey results and response rate. See Chapter $V$, Section 2 for further discussion.

Attached to those questionnaires mailed to two former clients in the same household was a request that responses be completed individually by each participant.

In the first mail-out, questionnaires were sent to the total sample of 168 persons. Thirty-one responses (18 percent) were received prior to the second mail-out two and one-half weeks later. Letters 
returned by the post office were readdressed and mailed, when possible. Seven questionnaires ( 4 percent) were eventually returned as undeliverable. Two weeks after the second mailing, a total of sixty-three responses ( 36 percent) had been received.

Between two and three weeks after the second mail-out, an effort was made to telephone each remaining nonrespondent (with the exception of those persons residing outside the area or with no known phone) to encourage participation in the survey. Telephoning was conducted by agency staff. Of ninety-six nonrespondents, a total of sixty-four (66 percent) were reached; twenty-two of these (34 percent) eventualiy returned completed questionnaires. In contrast, of the thirty-two nonrespondents not reached by telephone, six (19 percent) eventually participated in the study.

A response cut-off date was established six weeks after the second mailing (eight and one-half weeks after the initial mailing). At this time, ninety-one completed questionnaires (54 percent) had been received. In order to assess the possible differences between respondent and nonrespondent consumer feedback, a random sample of eight nonrespondents (10 percent) was drawn to be interviewed by telephone. Telephoning was conducted by agency staff members. Seven individuals from the sample were reached and interviewed; one individual refused to participate. Three priority questions were selected from the questionnaire for the telephone interviews; in addition, comments were solicited regarding possible preferred alternatives to the mail-out questionnaire method of consumer survey. A list of telephone interview questions may be found in Appendix E. 
This method of data gathering was chosen because the chances of participation by mail (after two previous mailings) seemed remote, and in-person interviews would have required appointment setting by telephone, and a possibly high rate of refusal to participate. A response bias may have been introduced through the use of a data collection method different than the mail-out questionnaire technique. 


\section{CHAPTER IV}

\section{DATA ANALYSIS}

The first two sections in this chapter present the characteristics of the sample and an analysis of the differences in characteristics between the respondents and nonrespondents. The next sections provide the responses to the mail-out questionnaire and to the telephone sample of . nonrespondents.

The last sections of this chapter include analyses of the couples' perceptions of the agency, a correlation between two questions from the questionnaire, and the results from multiple regression analyses of the relationships between the clients' characteristics and their responses on the questionnaire.

\section{SECTION 1, CHARACTERISTICS OF THE STUDY SAMPLE}

The following list indicates those characteristics of clients which were examined in this study:

Sex

Marital status (before, during, or after divorce)

Age

Income

Education

Number of children

Ages of children 
Previous counseling; no previous counseling

Wanted divorce; did not want divorce

Number of sessions attended at Family Court Service

Issue which brought the client to Family Court Service was reconciliation, custody/visitation, or split issues

Closing date of case

These variables were chosen by reviewing similar studies and adding additional variables the researchers believed to be pertinent. The variables were then reviewed by the staff at Family Court Service.

Four groups comprised the study sample of 176 individuals. There were ninety-one individuals in the group of respondents, seventy in the group of nonrespondents, seven individuals in the sample of nonrespondents, and eight in the pre-test sample.

As can be seen in Table 1, the sample had an average age of thirty-two years and included slightly more females than males. The number of children of the individuals in the study ranged from zero to seven, with the average being two. Only those children under the age of eighteen were reported because the agency gives priority service to individuals with minor children.

The average monthly income was $\$ 732$ which is considerably lower than the estimated monthly family median income of $\$ 1,297$ for Clackamas County. The accuracy of the reported incomes in this study is questionable. Information on income was collected at the time of case intake, and clients may have reported solely their own income or they may have reported joint income with a spouse. Women who had remarried may not have reported their new spouses' incomes, which may be one explanation 
TABLE 1

CHARACTERISTICS OF THE SAMPLE

\begin{tabular}{|c|c|c|}
\hline Characteristics & Number & Percent \\
\hline $\begin{array}{l}\text { Sex: } \\
\text { Female } \\
\text { Male }\end{array}$ & $\begin{array}{l}92 \\
84 \\
\end{array}$ & $\begin{array}{l}52 \\
48 \\
\end{array}$ \\
\hline Total & 176 & 100 \\
\hline $\begin{array}{l}\text { Age: } \\
\qquad \begin{array}{l}16-24 \\
25-34 \\
35-44 \\
45-54 \\
55-60 \\
\text { Missing information }{ }^{2}\end{array}\end{array}$ & $\begin{array}{r}25 \\
87 \\
35 \\
12 \\
2 \\
15 \\
\end{array}$ & $\begin{array}{r}14 \\
49 \\
19 \\
7 \\
1 \\
9 \\
\end{array}$ \\
\hline Total & 176 & 100 \\
\hline 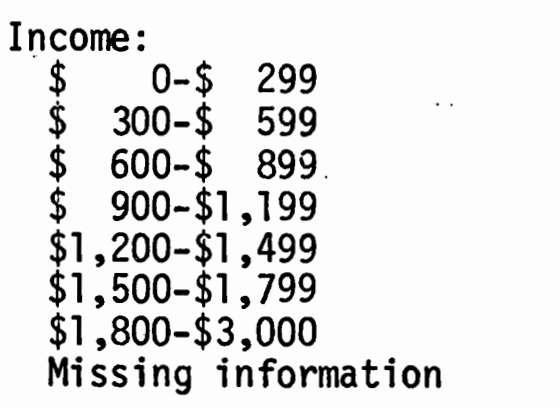 & $\begin{array}{r}27 \\
37 \\
18 \\
17 \\
12 \\
10 \\
5 \\
50 \\
\end{array}$ & $\begin{array}{r}15 \\
21 \\
10 \\
10 \\
7 \\
6 \\
3 \\
28 \\
\end{array}$ \\
\hline Total & 176 & 100 \\
\hline $\begin{array}{l}\text { Education: } \\
\text { Non-high school graduate } \\
\text { High school graduate } \\
\text { Some college } \\
\text { Missing information }\end{array}$ & $\begin{array}{l}22 \\
68 \\
57 \\
29 \\
\end{array}$ & $\begin{array}{l}13 \\
39 \\
32 \\
16 \\
\end{array}$ \\
\hline Total & 176 & 100 \\
\hline $\begin{array}{l}\text { Marital Status: } \\
\text { Before divorce } \\
\text { During divorce } \\
\text { After divorce }\end{array}$ & $\begin{array}{l}43 \\
67 \\
66 \\
\end{array}$ & $\begin{array}{l}24 \\
38 \\
38 \\
\end{array}$ \\
\hline Total & 176 & 100 \\
\hline
\end{tabular}

${ }^{a}$ Missing information in this table and in Table 2 resulted from clients not filling out the intake application or portions of the intake application. 
of why 7 percent of the sample had no reported income. Another explanation may be that the women were recently separated and had no established income. The high rate of missing information on reported incomes (28 percent), combined with 7 percent with no reported income, adds to the difficulty of a reliable use of this variable in the study.

Sixty-nine individuals ( 39 percent) reported having had previous counseling before coming to the Family Court Service. Previous counseling was defined as at least one contact by the client with a psychiatrist, psychologist, marriage counselor, clergyman, or other mental health professionat.

At the time of the intake interview with a counselor, one-quarter of the sample stated that they wanted a divorce while one-quarter reported they did not want a divorce. Five percent of the sample stated they did not know if they wanted the divorce. This information was not collected from those individuals whose divorces were already final at the time they made application to the Family Court Service (38 percent of the sample).

The major issues bringing individuals to the Family Court Service were custody/visitation, reconciliation, and split issues. Split issues was defined as the counselor indicating that one partner (in before divorce or during divorce cases) wanted the divorce and was interested in negotiating custody/visitation disagreements, while one person did not want the divorce and was interested in counseling for reconciliation. One hundred two individuals ( 58 percent) came to the agency to negotiate custody/visitation differences, thirty-three individuals (19 
percent) wanted reconciliation counseling, and forty individuals (23 percent) were involved in split issue situations.

The average number of visits per client was about three. Slightly less than one-quarter of all clients were only seen once.

Couples comprised different proportions of the various groups in the sample (respondents, nonrespondents, telephone sample of nonrespondents, and pre-test sample). There were twenty-three couples (51 percent) in the group of ninety-one respondents. Fifteen couples comprised 43 percent of the nonrespondents. There were two couples in the telephone sample of nonrespondents, and three couples in the pre-test sample, making a total of forty-three couples in the entire study sample.

\section{SECTION 2, ANALYSIS OF THE DIFFERENCES IN CHARACTERISTICS BETWEEN RESPONDENTS AND NONRESPONDENTS}

Table 2 shows the characteristics which were analyzed to determine whether there was a statistically significant difference between the questionnaire respondents and nonrespondents. A chi square test utilizing contingency tables indicated that there was a statistically. significant difference between respondents and nonrespondents as to their marital status. Individuals who used the agency while in the process of divorce returned questionnalres at a significantly lower rate than individuals who used the agency before they filed for divorce or after their divorce was final. The only other statistically significant difference in characteristics between the respondents and the nonrespondents was average age at the time of application to the Family court Service. A 
t-test determined that respondents were significantly older than nonrespondents, 33.4 versus 30.6 years of age.

TABLE 2

DIFFERENCES IN CHARACTERISTICS BETWEEN RESPONDENTS AND NONRESPONDENTS

\begin{tabular}{lcc}
\hline \multicolumn{1}{c}{ Characteristics } & Respondents & Nonrespondents \\
\hline Sex: & & \\
Female & $56 \%$ & $49 \%$ \\
Male & $44 \%$ & $51 \%$ \\
Marital Status : & & \\
Before divorce & $29 \%$ & $17 \%$ \\
During divorce & $30 \%$ & $50 \%$ \\
After divorce & $42 \%$ & $33 \%$ \\
Average Age & 33.4 & 30.6 \\
Average Monthly Income & $\$ 686$ & $\$ 781$ \\
Education: & & \\
Non-high school graduate & $8 \%$ & $17 \%$ \\
High school graduate & $40 \%$ & $39 \%$ \\
Some college & $33 \%$ & $31 \%$ \\
Missing information & $20 \%$ & $13 \%$ \\
Had Previous Counseling: & & \\
Yes & $45 \%$ & $33 \%$ \\
No & $34 \%$ & $47 \%$ \\
Missing information & $21 \%$ & $20 \%$ \\
Wanted the Divorce: & & \\
Yes & $19 \%$ & $31 \%$ \\
No & $24 \%$ & $23 \%$ \\
Don't know & $4 \%$ & $4 \%$ \\
Not applicable & $42 \%$ & $33 \%$ \\
Missing information & $11 \%$ & $3 \%$ \\
Average Number of Sessions Attended & 3.45 & 3.20 \\
Issues Which Brought Individual to & & \\
Family Court Service: & $19 \%$ & $5 \%$ \\
Reconciliation & $58 \%$ & \\
Custody/visitation & $1 \%$ & \\
Split issues & & \\
Missing information & & \\
\hline & & \\
\hline
\end{tabular}

atatistically significant: $x^{2}=7.26 ; d f=2 ; p .<.05$

${ }^{b}$ Statistically significant: $t=2.07 ; p .<.05$ 
Although there were differences in characteristics between the respondents and the nonrespondents, a statistical analysis of a sample of nonrespondents contacted by telephone suggested that respondents and nonrespondents were similar in their answers to questions on the questionnaire. This is discussed in further detail in Section 4 of this chapter.

\section{SECTION 3, RESPONSES TO THE MAIL-OUT QUESTIONNAIRE}

There were two parts to the first question on the instrument. The first part asked the former clients their opinions regarding agency helpfulness, "Was your involvement with the Family Court Service helpful or not helpful?" The second part was an open-ended question in which participants were asked in what ways agency involvement was helpful or unhelpful. A code to classify the responses was developed and refined to the point where two independent coders were able to use it with a 95 percent rate of agreement.

Table 3 shows that 60 percent of the respondents marked very helpful or somewhat he1pful on the first part of question number one. Table 4 shows the ways in which clients saw the agency to be helpful or unhelpful, as well as examples from the questionnaires for each category. The major way in which the clients found the Family Court Service to be helpful was in learning new or better problem-solving skills with regard to parental and/or marital issues. The major reason clients believed the Family Court Service was not helpful was that they were unable to accomplish the goal(s) which brought them to the agency. 
TABLE 3

CLIENTS' PERCEPTIONS OF AGENCY HELPFULNESS OR UNHELPFULNESS Clients! Perceptions Number

Percent

Helped a great deal

Helped somewhat

Was somewhat unhelpful

Was very unhelpful

Not sure

Missing information ${ }^{2}$

Total

28

26

9

18

5

$\underline{5}$

91
31

29

10

20

5

$\frac{5}{100}$


sulted from respondents not completing portions of the questionnaire.

TABLE 4

WAYS IN WHICH CLIENTS SAW AGENCY TO BE HELPFUL OR UNHELPFUL

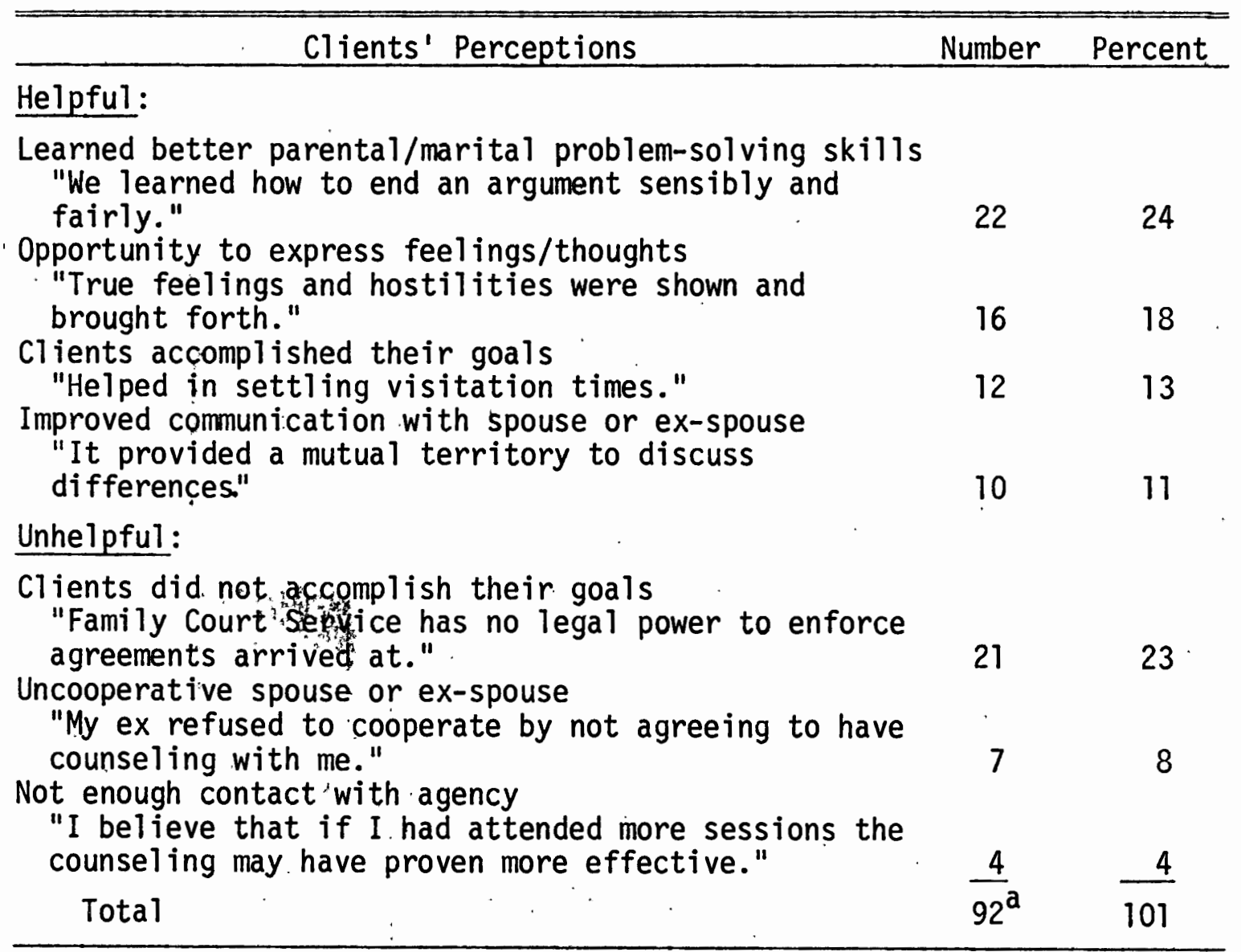

${ }^{a}$ Total varies from ninety-one because of multiple or no responses. 
Three of the questions on the questionnaire were designed to reflect three agency objectives: cooperative parenting, conflict management, and positive adjustment of children. Table 5 shows the results to the question intended to measure client learning regarding cooperative parenting skills, "Did using the Family Court Service help you and your spouse or ex-spouse work together as parents?" Twenty-nine percent of the respondents indicated they found their contact with the Family Court Service heiped somewhat or a great deal in this learning. Fiftyfour percent of the respondents either marked not sure or does not apply, or did not respond to this question.

TABLE 5

CLIENTS' PERCEPTIONS OF AGENCY HELPFULNESS IN LEARNING COOPERATIVE PARENTING SKILLS

\begin{tabular}{lcc}
\hline \multicolumn{1}{c}{ Clients' Perceptions } & Number & Percent \\
\hline Helped a great deal & 5 & 5 \\
Helped somewhat & 22 & 24 \\
Was somewhat unhelpful & 4 & 4 \\
Was very unhelpful & 11 & 12 \\
Not sure & 9 & 10 \\
Does not apply & 30 & 33 \\
Missing information & $\underline{10}$ & $\underline{11}$ \\
Total & 91 & 99 \\
\hline
\end{tabular}

Table 6 shows the responses to another agency objective as reflected in the question regarding learning of conflict management skills, "Do you think that you learned how to better handle your differences with your spouse or ex-spouse?" Forty-two percent of the respondents indicated that they learned some or a great deal. Twenty-three percent said they didn't learn much or didn't learn at all, and 34 percent marked not sure or does not apply, or failed to answer this question. 
TABLE 6

\section{CLIENTS' PERCEPTIONS OF AGENCY HELPFULNESS}

IN LEARNING CONFLICT MANAGEMENT

\begin{tabular}{|c|c|c|}
\hline Clients ' Perceptions & Number & Percent \\
\hline $\begin{array}{l}\text { Learned a lot } \\
\text { Learned some } \\
\text { Didn't learn much } \\
\text { Didn't learn at all } \\
\text { Not suge } \\
\text { Does not apply } \\
\text { Missing information }\end{array}$ & $\begin{array}{r}14 \\
25 \\
9 \\
12 \\
3 \\
18 \\
10 \\
\end{array}$ & $\begin{array}{r}15 \\
27 \\
10 \\
13 \\
3 \\
20 \\
11 \\
\end{array}$ \\
\hline Total & 91 & 99 \\
\hline
\end{tabular}

Table 7 indicates the results to another agency objective as reflected in the question regarding children!s positive adjustment, "Did you learn how to better help your children adjust to your family problems, separation, or divorce?" Almost half indicated they learned some or a lot. Fourteen percent thought they didn't learn much or did not learn at all. Forty percent marked not sure or does not apply, or did not answer this question.

TABLE 7

CLIENTS' PERCEPTIONS OF AGENCY HELPFULNESS IN LEARNING TO HELP CHILDREN ADJUST TO FAMILY PROBLEMS, SEPARATION, OR DIVORCE

\begin{tabular}{lcc}
\hline \multicolumn{1}{c}{ Clients' } & Perceptions & Percent \\
\hline Learned a lot & 14 & 15 \\
Learned some & 28 & 31 \\
Didn't learn much & 6 & 7 \\
Didn't learn at a11 & 6 & 7 \\
Not sure & 2 & 2 \\
Does not apply & 25 & 27 \\
Missing information & 10 & 11 \\
Total & 91 & 100 \\
\hline
\end{tabular}


On the last three questions discussed, a large percentage of the respondents marked not sure or does not apply, or did not answer the question. This issue is addressed in Chapter V, Section 3, in the discussion of questionnaire design.

There were two parts to the question on the instrument regarding satisfaction with the counselor. The first part asked the former client, "Were you satisfied with your counselor's assistance to you and your family?" The second part was an open-ended question in which former. clients were asked in what ways they were satisfied or dissatisfied with their counselor's assistance. A code to classify the responses was developed and refined to the point where. two independent coders were able to use it with a 93 percent rate of agreement.

Table 8 shows that more than two-thirds of the respondents were somewhat or very satisfied with the assistance they received. Table 9 indicates the ways in which clients were satisfied or dissatisfied with their counselor's assistance, as well as examples from questionnaire responses for each category. The major reason for clients' satisfaction with their counselor's assistance was the counselor's abilities and qualities, such as being understanding and fair. One of the reasons clients were not satisfied with their counselor's assistance was disapproval of the counselor's actions or an agency policy. Another reason clients were dissatisfied was related to the qualities or skills of the counselor, such as being biased toward one person.

The next question on the instrument asked about the number of sessions attended, "What did you think of the number of sessions you attended at the Family Court Service?" Table 10 shows that 42 percent 
TABLE 8

CLIENTS' PERCEPTIONS REGARDING SATISFACTION WITH COUNSELOR'S ASSISTANCE

\begin{tabular}{|c|c|c|}
\hline Clients' Perceptions & Number & Percent \\
\hline $\begin{array}{l}\text { Very satisfied } \\
\text { Somewhat satisfied } \\
\text { Dissatisfied in some ways } \\
\text { Very dissatisfied } \\
\text { Not sure } \\
\text { Missing information }\end{array}$ & $\begin{array}{r}48 \\
15 \\
5 \\
14 \\
2 \\
7 \\
\end{array}$ & $\begin{array}{r}53 \\
16 \\
5 \\
15 \\
2 \\
8 \\
\end{array}$ \\
\hline Total & 91 & 99 \\
\hline
\end{tabular}

\section{TABLE 9}

WAYS IN WHICH CLIENTS WERE SATISFIED OR DISSATISFIED WITH COUNSELOR'S ASSISTANCE

\section{Clients' Perceptions}

Number

Percent

Satisfied:

Counselor had good qualities

"Our counselor had the experience, kindness, and understanding that was needed."

Learned better parental/marital problem-solving skills

"The counselor helped me to accept some problems and to look at them from different perspectives." .

Helped to adjust or cope with the situation

"Helped me cope with the situation and accept it."

14

15

$9 \quad 10$

Dissatisfied:

Counselor's actions or agency policy unacceptable to

client

"We went mostly for husband's benefit, but our

counselor was more concerned about our children."

Counselor lacked competency

"Let ex-spouse keep hashing over the past."

Goals not met (not counselor or agency's fault)

"We just weren't ready to utilize counseling."

Total

14

12

13

$\frac{9}{94^{a}} \cdot \frac{10}{102}$

a Total varies from ninety-one because of multiple or no responses.

of the respondents were satisfied with the number of sessions they attended and 21 percent would have preferred more sessions. 
TABLE 10

CLIENTS' OPINIONS REGARDING THE NUMBER OF SESSIONS ATTENDED

\begin{tabular}{|c|c|c|}
\hline Clients' Opinions & Number & Percent \\
\hline $\begin{array}{l}\text { About right } \\
\text { Too few } \\
\text { Too many } \\
\text { Not sure } \\
\text { Missing information }\end{array}$ & $\begin{array}{r}38 \\
19 \\
3 \\
12 \\
19\end{array}$ & $\begin{array}{r}52 \\
21 \\
3 \\
13 \\
21 \\
\end{array}$ \\
\hline Total & 91 & 100 \\
\hline
\end{tabular}

Forty-eight percent of the respondents suggested ways to change the agency when asked, "What suggestions do you have for changing or improving any part of the agency?" Table 11 indicates the categories of suggested changes or improvements. Having more sessions and counseling or services for children were the categories with the most responses.

TABLE 11

CLIENTS' SUGGESTIONS FOR CHANGING OR IMPROVING THE AGENCY

\begin{tabular}{lcc}
\hline \hline \multicolumn{1}{c}{ Clients' $^{\prime}$ Suggestions } & Number & Percent \\
\hline Have more sessions & 8 & 18 \\
Have counseling or services for children & 7 & 16 \\
Make services mandatory & 4 & 9 \\
Have more counselors or more flexible hours & 4 & 9 \\
Do not be biased in counseling & 4 & 9 \\
Advertise agency more & 2 & 5 \\
More emphasis on reconciliation & 2 & 5 \\
Miscellaneous & 9 & 20 \\
Personal complaints or observations (not suggestions) & $\frac{4}{9}$ & $\frac{9}{100}$ \\
Total & 44 & 10 \\
\hline
\end{tabular}

Twenty-one percent of the respondents suggested additional services when asked, "Was there any service not offered by the Agency that might have been of benefit to you or your family?" Table 12 shows that 
the majority of these suggestions were for some type of further counseling.

TABLE 12

ADDITIONAL SERVICES SUGGESTED BY CLIENTS

\begin{tabular}{lcc}
\hline \multicolumn{1}{c}{ Clients' } & Number & Percent \\
\hline More counseling: & 5 & \\
With children & 3 & 28.0 \\
Extended or follow-up sessions & 2 & 17.0 \\
Groups & 1 & 5.5 \\
With one parent & 1 & 5.5 \\
For single persons & 1 & 5.5 \\
For stepparents & 1 & 5.5 \\
Mandatory services & 1 & 5.5 \\
Offer P.E.T. classes & 3 & 17.0 \\
Miscellaneous & 18 & 100.5 \\
Total & 18 & \\
\hline
\end{tabular}

SECTION 4, ANALYSIS OF THE RESPONSES TO THE TELEPHONE SURVEY OF A SAMPLE OF NONRESPONDENTS

A sample of seven nonrespondents was interviewed by telephone in order to assess the possible differences between respondent and nonrespondent perceptions of the agency. (Chapter III, Section 5 discusses the process of this survey.)

Three priority questions were selected from the questionnaire for the interviews (see Appendix E). A sample ratio provided the estimated sample bias for the questions shown in Table $13^{1}$

The sample bias on the two questions regarding changing, improving, or adding services to the agency was fairly large. It was the

William G. Cochran, Sampling Techniques, 2nd ed. (New York: John Wiley \& Sons, Inc., 1953), p. 13. 
TABLE 13

ESTIMATED SAMPLE BIAS FROM A TELEPHONE SURVEY OF NONRESPONDENTS

Questions

Estimated Sample Bias

Was your involvement with the Family court

Service helpful or not helpful?

What suggestions do you have for changing or

improving any part of the Agency?

Was there any service not offered by this

Agency that might have been of benefit to

you or your family?

impression of the researchers, however, that this may have been more a function of how the clients were contacted than a significant difference between respondents and nonrespondents. The telephone contact may have introduced a bias not present for the mail-out questionnaire method. These two questions possibly require more thought and time to answer than any of the other questions. Individuals may have answered differently when being questioned by phone because they didn't have the same amount of time to respond as the clients answering a mail-out questionnaire.

The estimated sample bias on the question regarding agency helpfulness was very sma11. Because of this question's importance and similarity in form to the other questions on the questionnaire, the researchers were inclined to believe that respondents and nonrespondents tended to be similar in how they perceived the agency.

\section{SECTION 5, ANALYSIS OF COUPLES' PERCEPTION OF THE AGENCY}

The unit of study for this survey was the individual. However, it is agency policy to do counseling with couples whenever possible. It 
was deemed important, therefore, to examine whether or not spouses or, ex-spouses viewed the agency differently.

The responses to all the major questions from the questionnaire were analyzed to determine if there was a statistically significant difference in how spouses or ex-spouses responded. Using a t-test for paired comparisons, it was determined that there was no significant difference at the .05 level in how spouses or ex-spouses responded on the questionnaire.

\section{SECTION 6, ANALYSIS OF CORRELATION BETWEEN CLIENTS' PERCEPTIONS OF AGENCY HELPFULNESS AND SATISFACTION WITH COUNSELOR'S ASSISTANCE}

It could be argued that there should be a high correlation between the responses to the questions on the instrument regarding clients' perceptions of the helpfulness of the agency and clients' satisfaction with the counselor's assistance. In most instances, the major contact with the agency the client had was with the assigned counselor. Therefore, how the client viewed the counselor should be closely correlated with how the client viewed the agency.

The correlation coefficient for agency helpfulness and satisfaction with counselor's assistance equaled .61. An analysis of content on the open-ended questions regarding agency helpfulness and counselor satisfaction suggested that there were instances in which the client was satisfied with the counselor's assistance but the agency was not seen as helpful. The following response illustrates this point. "Family Court Service wasn't much help . . . my ex-wife was too set in her 
ways .. . [but] we had competent counseling." This type of response may partially explain why the correlation of .61 was not higher.

\section{SECTION 7, ANALYSIS OF THE RELATIONSHIP BETWEEN CHARACTERISTICS OF THE. RESPONDENTS AND THEIR RESPONSES ON THE QUESTIONNAIRE}

Multiple regression analyses empirically tested the relationships between the characteristics of the respondents and their answers on the questionnaire. In addition, the separate effects of different factors and the magnitude of each relationship were estimated.

The following list indicates those items which were chosen as independent variables for the regression:

Sex

Marital status (before, 'during', or after divorce)

Age

Education

Number of children

Ages of children

Previous counseling; no previous counseling

Wanted divorce; did not want divorce

Number of sessions attended at Family Court Service

Number of sessions attended was too many, about right, or too few

Issue which brought the client to Family Court Service was reconciliation, custody/visitation, or split issues

Closing date of case 
Five separate regressions were run in order to examine the relationship of the above items to responses to the five major questions from the instrument. These questions were: ${ }^{2}$

Do you think that you learned how to better handle your differences with your spouse or ex-spouse?

Were you satisfied with your counselor's assistance to you and your family?

Was your involvement with the Family Court Service helpful or not helpful?

Did using the Family Court Service help you and your spouse or ex-spouse work together better as parents?

Did you learn how to better help your children adjust to your family problems, separation, or divorce?

The regression in which the independent variables accounted for the greatest change in the dependent variable is shown in Table 14. This table presents an analysis of the relationship between the clients' characteristics and the responses to the question, "Do you think that you learned how to better handle your differences with your spouse or ex-spouse?" The most significant client characteristic, contributing .17 to the $R^{2}$, was the respondents' opinions of the number of sessions attended at the Family Court Service. Clients who stated that the number of sessions attended was about right also concluded that the agency helped them to acquire conflict management skilis.

${ }^{2}$ The regressions covering the first three questions listed were statistically significant (see Tables 14, 15, and 16). 
TABLE 14

ANALYSIS OF RELATIONSHIP BETWEEN CLIENTS' CHARACTERISTICS AND

LEARNING HOW TO BETTER HANDLE DIFFERENCES WITH

SPOUSE OR EX-SPOUSE

\section{Clients' Characteristics}

Contribution to $\mathrm{R}^{2}$

Thought the number of sessions attended at FCS was about right

Closing date of client's file

. $.17^{\mathrm{a}}$

$.11^{b}$

Thought the number of sessions attended at FCS

was too many

Issue which brought client to FCS was reconciliation

other independent variables

$$
R^{2}=\frac{.15}{.54 C}
$$

The second most significant characteristic, which contributed .11 to the $R^{2}$, was the closing date of the clients' files. The longer the period of time from when the client was last seen at the agency, the more the client indicated was learned in conflict management skills.

Overall, the four characteristics shown in Table 14 accounted for 72 percent of the $R^{2}$. The other independent variables, listed earlier in this section, contributed in various degrees to the remaining variance.

Table 15 presents the multiple regression analysis of the relationship between clients' characteristics and the responses to the question, "Were you satisfied with your counselor's assistance to you and your family?" As in the first regression discussed, the most 
significant independent variable was the respondents' opinions of the number of sessions attended at the Family Court Service. This variable contributed .11 to the $R^{2}$. If the $c l i e n t s$ stated that the number of sessions attended was about right, there was a tendency to conclude that the counselor's assistance was satisfactory.

\section{TABLE 15}

\section{ANALYSIS OF RELATIONSHIP BETWEEN CLIENTS' CHARACTERISTICS AND SATISFACTION WITH COUNSELOR'S ASSISTANCE}

\begin{tabular}{lc}
\hline \multicolumn{1}{c}{ Clients' Characteristics } & Contribution to $R^{2}$ \\
\hline Thought the number of sessions attended at & $.11^{\mathrm{a}}$ \\
FCS was about right & .06 \\
Issue which brought client to FCS was recon- & .05 \\
ciliation & .05 \\
Number of sessions attended at FCS & .11 \\
Thought the number of sessions attended at & \\
FCS was too many & $\mathrm{R}^{2}=.38^{\mathrm{b}}$ \\
Other independent variables &
\end{tabular}

$$
\begin{aligned}
& a_{F}=11.19 ; d f=1,62 ; p .<.01 \\
& b_{F}=1.97 ; \text { df }=.19,62 ; \text { p. }<.05
\end{aligned}
$$

The second most significant characteristic, which contributed .06 to the $R^{2}$, was reconciliation as the reason for agency involvement. If the issue which brought the couple to the agency was reconciliation, as opposed to custody/visitation or split issues, there was a tendency for the individual client to indicate satisfaction with the counselor's assistance. 
The four characteristics shown in Table 15 overall acccounted for 71 percent of the $R^{2}$. The other independent variables listed earlier in this section contributed to the remaining variance.

The multiple regression analys is shown in Table 16 presents the relationship between the clients' characteristics and the question, "Was your involvement with the Family Court Service helpful or not helpfu1?" As in the other two regressions discussed, the most significant client characteristic was the respondents' opinions of the number of sessions attended at the agency. In this regression, this variable contributed .09 to the $R^{2}$. If the clients stated that the number of sessions attended was about right, they also tended to conclude that their involvement with the agency was helpful.

\section{TABLE 16}

ANALYSIS OF RELATIONSHIP BETWEEN CLIENTS' CHARACTERISTICS AND WHETHER OR NOT THEY FOUND THE FCS HELPFUL

\section{Clients' Characteristics} Contribution to $\mathrm{R}^{2}$

Thought the number of sessions attended at FCS was about right

$$
\begin{array}{r}
.09^{\mathrm{a}} \\
.06 \\
.05 \\
.03 \\
\mathrm{R}^{2}=\frac{.13}{.36^{b}}
\end{array}
$$$$
\text { Number of sessions attended at FCS }
$$$$
\text { Thought the number of sessions attended at }
$$$$
\text { FCS was too many }
$$$$
\text { Before divorce marital status }
$$$$
\text { Other independent variables }
$$

$$
\begin{aligned}
& a_{F}=8.61 ; \text { df }=1,61 ; \text { p. }<.01 \\
& b_{F}=1.83 ; \text { df }=.19,61 ; \text { p. }<.05
\end{aligned}
$$

The second most significant characteristic in this regression was very similar to the first characteristic. It was the number of 
sessions actually attended at the agency. Clients who attended more sessions tended to view agency involvement as more helpful. This characteristic contributed .06 to the $R^{2}$.

The four characteristics shown in Table 16 accounted for 64 percent of the $R^{2}$. The remaining variance was accounted for by the other independent variables which were listed earlier in this section.

The characteristic which was consistently the most significant for each of the regressions was the clients' opinions that the number of sessions attended was about right. Tables 14, 15, and 16 show that another important characteristic was the clients' opinions that the number of sessions attended at the agency was too many. If the clients stated that the number of sessions attended was too many, they also tended to state that their involvement with the agency was not helpful. 
CHAPTER $V$

\section{IMPLICATIONS AND RECOMMENDATIONS}

This chapter discusses the questionnaire results and the implications of the study. In addition, an analysis of questionnaire response rate, a critique of the evaluation process, study sample, and the questionnaire, and recommendations for the development of an ongoing consumer evaluation system are included.

\section{SECTION 1, QUESTIONNAIRE RESULTS AND IMPLICATIONS} FOR THE FAMILY COURT SERVICE

Findings from two of the questions measuring client satisfaction with agency services can be compared to findings from similar questions included in three of the studies discussed in Chapter II. The Family Court Service study found that 60 percent of the respondents reported agency involvement was very helpful or somewhat helpful, while 69 percent of the respondents were very satisfied or somewhat satisfied with the counselor's assistance. The Wayne County study reported that 75 percent of the respondents found agency involvement to be very helpful or somewhat helpful. ${ }^{1}$. The Hennepin County study found that 85 percent of the respondents would recommend the program to someone else. ${ }^{2}$ The Maricopa County study reported that 79 percent of the respondents would

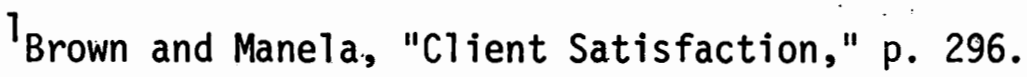

2 Rhodes and Ihlow, "Evaluation Findings," p. 3. 
recommend the service to a friend and that 53 percent felt that the agency had helped them reach some satisfactory decision. This study also reported that 70 percent of the respondents evaluated their counselors positively. ${ }^{3}$

The variety in these reported responses may reflect the differences in study designs and the different types of services provided by these four agencies. For example, not only were different or slightly different questions asked, but the length of time from provision of services to completion of questionnaires also varied greatly. In addition, the programs the clients were asked to evaluate differed in duration and objectives. The numerous differences among these four studies contribute to the difficulty of meaningful comparisons; however, it appears as though the responses from the Family Court Service evaluation regarding agency helpfulness and satisfaction with counselor assistance are similar to the responses reported in the cited studies.

Responses to the Family Court Service questionnaire included a wide variety of perceptions of agency helpfulness or lack of helpfulness and satisfaction or dissatisfaction with the counselor's assistance. The Wayne County study also received a variety of client responses regarding what was accomplished in counseling. From these results, Brown and Manela concluded that "these different kinds of counseling needs are likely to require different approaches to treatment and delivery of a variety of services. "4 similarly, it might be

3 Furman et al., "Clients' Perceptions," p. 33.

4 Brown and Manela; "Client Satisfaction," p. 302. 
recommended that the Family Court Service counseling program be as flexible as possible so as to accommodate the individual needs of clients. Although it is clear that not all of the respondents in the Family Court Service study found agency involvement to be helpful, nor were all satisfied with the counselor's assistance, the majority clearly felt that they were helped and were satisfied. Given the variety of client needs and the limitations on how an agency can realistically fulfill these needs, the Family Court Service must now decide if program modification is in order based on the client feedback received.

When asked their opinion regarding the number of counseling sessions, 22 percent of the respondents stated that they had attended too few sessions. In addition, when clients were asked for suggestions for changing or improving the service, the most frequent response (from 18 percent of those answering this question) was a request for more counseling sessions. When clients were asked to suggest additional services from which they might have benefitted, 17 percent of those responding suggested extended or follow-up sessions for themselves or family members.

These results may indicate that some clients would have liked to have been more involved in the decision-making process regarding number of counseling sessions. Or, in some cases the number of sessions may have been too few for reasons beyond the control of the agency, such as a spouse or ex-spouse refusing to attend more sessions. The Maricopa County study reported an even larger percentage of participants (42 percent) who indicated that the number of counseling sessions were too few. 
(It appears as though the number of sessions was limited to three at this agency. ${ }^{5}$ ) Needless to say, an agency may not always be able to accommodate all the requests for its services, and the clients' needs have to be balanced by the agency's available resources. From the consumer's point of view, however, it would be preferable to have as much client involvement as possible in decision making regarding the number of sessions.

When clients were asked for suggestions for changing or improving the agency, 16 percent of those responding to this question recommended counseling or services for children. When asked for suggestions for additional services, 28 percent of the respondents answering this question stated that their families might have benefitted from more counseling with, for, or about children. It is agency policy to include children in counseling when the parents and counselor agree that it is appropriate. It is therefore unclear why these respondents indicated a need for this type of further service. Possibly the agency needs to make this part of their program more visible in order that all clients realize the availability of counseling with or about children.

One of the tasks of this study was to analyze the characteristics of those clients who reported more satisfaction with the Family Court Service compared to those who reported less satisfaction. The Wayne County study also addressed this issue and found that the major characteristics associated with client satisfaction were the number of sessions attended and sex and race. Those clients who attended more

Furman et al., "Clientș' Perceptions," p. 27. 
sessions were significantly more satisfied than those attending fewer sessions. When black and white men and women were compared white women were found to be significantly more satisfied with agency services. 6

The Family Court Service study also found the number of sessions attended to be a highly significant characteristic associated with client satisfaction with services. As might be expected, those clients who stated that the number of sessions attended was about right also indicated a higher level of satisfaction.with the agency.

Sex was not found to be a variable which contributed significantly to client satisfaction in the Family Court Service evaluation. Race was not examined as a variable because the vast majority of the clients were Caucasian. This reflected the racial composition of the county population.

Multiple regression analyses showed that the twelve client characteristics ${ }^{7}$ selected each contributed varying amounts to client satisfaction or dissatisfaction with agency involvement. However, the effect of the twelve characteristics added together did not explain all of the variance. (The characteristics accounted for 54 percent, 38 percent, and 36 percent of the variance in the three statistically significant regressions.) It is recommended that future research examine additional variables in order to attempt to explain a larger percentage of the variance in consumer evaluation responses.

${ }^{6}$ Brown and Manela, "Client Satisfaction," p. 301. 7 See Chapter. IV, Section 7 for a list of the variables. 


\section{SECTION 2, QUESTIONNAIRE RESPONSE RATE AND \\ IMPLICATIONS FOR THE FAMILY \\ COURT SERVICE}

The questionnaire response rate for this study may be compared to response rates for the five previously discussed consumer evaluation studies of family court services. It was deemed important to examine response rates since a low response rate in any study may make it difficult to generalize the results of the survey to the entire study sample. Also, a comparison of response rates may assist in determining what may be anticipated for a response rate in future studies of this type.

The Family Court Service study obtained a response rate of 54 percent from 168 former clients. No individuals were dropped from the sample during the course of the study.

The Maricopa County study obtained a 53 percent response rate from 178 individuals by using methods similar to those of the Family Court Service project (two questionnaire mail-outs and telephone contact with nonrespondents between mail-outs). However, in the Maricopa County study twenty-two clients were dropped from the sample because they were known to have not received questionnaires. 8

In the Multnomah County study, a response rate of 25 percent was obtained from a sample of 260 individuals. Eight clients who were known to have not received questionnaires were excluded in the calculation of of the response rate. The Multnomah County study utilized a very short questionnaire printed on a postcard, and only one mail-out was completed. 9

${ }^{8}$ Furman et al., "Clients' Perceptions,". p. 29.

${ }^{9}$ Dudley et al., "Client Evaluation," p. 39. 
In Elkin's discussion of the Los Angeles County service, a followup response rate of 95 percent was claimed. It is not known what methods were used to obtain this rate, nor if responses were solicited from individuals or couples. 10

The Hennepin County study used data collected from participants at the close of weekly divorce experience programs. No response rate for this project is available because only those clients who completed questionnaires were included in the study. ${ }^{11}$

In the Wayne County study, two personal interviews were completed with 65 percent of the total sample of 659 eligible clients. It should be noted that consumer feedback was the topic of only two interview questions, and that eighty-five of the participants. were still involved in agency counseling at the time of the study. ${ }^{12}$

Analys is of findings from the Family Court Service study revealed that respondents and nonrespondents differed on only two client characteristics. These characteristics were marital status and age (see Chapter IV, Section 2). In the Multnomah County study, it was found that a significantly higher rate of response was obtained from individuals whose cases had been closed for a longer period of time. ${ }^{13}$ This finding was not substantiated in the Family Court Service study. Findings from the Wayne County study indicated that a significantly higher rate of

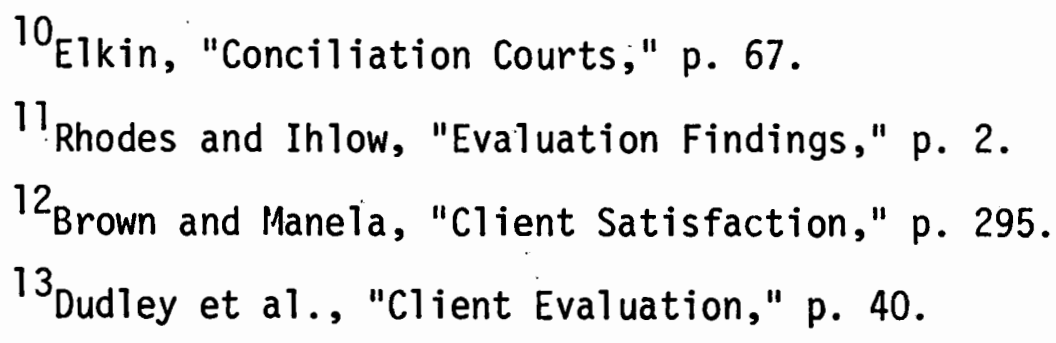


participation in personal interviews was obtained from women than men, and from white clients than black clients. ${ }^{14}$ As previously discussed, the Family Court Service study did not include an examination of the race factor. A differential response rate for men and women was not found in this study.

The diversity of response rates for the Family Court Service study and the other cited studies indicate that methodology, type of service, and other variables have an impact on the rate of participation in consumer evaluation projects.

The mail-out questionnaire method presents difficulties in obtaining a high response rate. One tactic for increasing participation might be the use of authority in connection with data collection. Nass and McIntyre, for example, suggest the utilization of organizational channels in the collection of mail-out questionnaire responses. ${ }^{15}$ As mentioned in Chapter III, Section 5, cover letter signature by a Circuit Court Judge was considered in this study; ultimately, it was decided that cover letters would be signed by the agency director. Cover letter signature by either a judge or the agency director could have affected survey results. The Family Court Service Director carries direct service cases; thus, a response bias may have been introduced for those former clients who had the director assigned as their counselor. It was thought that signature by a judge might increase the survey response

14 Brown and Manela, "Client Satisfaction," p. 295.
${ }^{15}$ Gilbert D. Nass and Walter G. McIntyre, "Improving Response Rates to Mail Questionnaires in Family Life Research," The Family Coordinator 18 (July 1969):241. 
rate. However, several of the individuals involved in pre-testing the instrument indicated that the association with the court might influence their questionnaire responses. A comparative study of response rate and response content using cover letters signed by a judge and by the director would indicate the actual influence. (if any) of this variable.

Even though it is important to obtain as high a response rate as possible from the study sample, the results from the sample of nonrespondents in the Family Court Service study suggested that respondents and nonrespondents did not differ markedly in their views of the agency (see Chapter IV, Section 4). This adds to the feasibility of assuming that the results obtained from the questionnaire were indicative of the entire study sample.

\section{SECTION 3, CRITIQUE OF THE EVALUATION PROCESS, STUDY SAMPLE, AND QUESTIONNAIRE}

The evaluation process chosen for this study (discussed in Chapter III) emphasized staff involvement in evaluation planning, execution, and use of study results. This emphasis corresponded with the agency's focus on staff decision making, and possibly contributed to the helpfulness of the study to the agency. A difficulty with the use of staff involvement in evaluation is that it is a time-consuming process that may not be possible in some agency situations. In addition, although the period under study in this project was the previous year of service, staff goal and objective identification did not occur until the end of the period. (It would have been preferable to complete this identification prior to the period under study.) As previously mentioned, the setting of criteria for program success was not accomplished. Criteria 
setting, and other issues related to the development of an ongoing consumer feedback system are discussed in Section 4 of this chapter.

The sample chosen for this study included individuals whose cases had been closed for one month to one year. As discussed in Chapter IV, the length of time since clients had been involved with the agency did not affect the content of consumer evaluation responses. This finding does not correspond with the assumptions for sample selection in the Maricopa County study. In that study, a sample was chosen from recently completed cases with the assumption that this insured more accurate responses and less loss of memory. ${ }^{16}$ While findings from the Family Court Service study indicate that case closing date may not be an important factor for sample selection in this type of survey, the issue would seem to warrant further research.

The sample used in the Family Court Service study did not include children, which seems inconsistent with the agency's emphasis on family involvement in counseling. The inclusion of children would have presumably necessitated the development of an additional data gathering instrument or instruments, and there is little precedent in the collection of consumer feedback from children. Nevertheless, this is an area of consumer evaluation that demands future efforts.

An analysis of the questionnaire used in this study reveals several possible problems. A high percentage of respondents indicated that the questions reflecting the agency objectives of positive adjustment of children, conflict management, and cooperative parenting did not apply

${ }^{16}$ Furman et a1.; "Clients' Perceptions," p. 27. 
to their situation (see Tables 5, 6, and 7 in Chapter IV, Section 3). There may have been various reasons for this result. First, wording of these questions may not have been satisfactory. Although a simple pretest was conducted (see Chapter III, Section 4), more extensive testing would be required to examine possible problems with questionnaire wording and to test for validity and reliability. Second, the three questions regarding agency objectives were fairly specific and may have been difficult to answer for the 45 percent of the sample who only attended one or two sessions. Third, it is possible that a portion of the clients felt that one or more of the three agency objectives were not applicable to their situation. Giordano discusses the difficulty of conducting consumer evaluation when clients may not recognize the legitimacy of agency goals and objectives. 17 Because the other items on the questionnaire did not offer the response "Does not apply," it is difficult to make any comparisons with client responses in other areas.

Whatever the reasons may have been for the high percentage of respondents indicating that these questions were not applicable, it is recommended that the Family Court Service attempt to determine if its priority objectives are being adequately stressed in the counseling program. It is also recommended that the agency clarify whether counseling should focus on all three objectives in most cases, or whether counseling might appropriately center on one or two of the objectives in many cases. Clarification in this area is necessary for future setting of criteria for program success.

${ }^{17}$ Giordano, "Clients Perspective," p. 36. 
As mentioned in Chapter III, Section 4, the order of listed choices on the multiple choice questions was deliberately varied. While this was intended to minimize the possible influence of the order of choices, the varied listing may have caused difficulties for some respondents. By comparing multiple choice responses with open-ended comments, it was apparent that in at least a few cases clients did not read the list of choices correctly and marked the wrong response. It is not known whether the number of incorrect responses exceeded the number that might have occurred with an instrument that consistently listed multiple choice options in the same order. Also, it is not known whether the incorrect responses on the Family Court Service questionnaire outweighed the possible benefits of varying the order of choices.

Finally, it should be noted that the questionnaire used in this study combined three evaluation topics: one, outcome of services based on client reports; two, analys is of counseling process (opinion of counselor's assistance and number of sessions); and three, assessment of needed additional or improved services. In the five previously discussed family court service studies, various combinations of these topics were included in the study instruments.

There may have been two disadvantages in including all three areas on the Family Court Service questionnaire. First, no single area was addressed in detail, although this would have been possible with the use of a longer instrument. Second, the agency may not be able to utilize study findings in all three areas; an agency focus on one or perhaps two topics seems likely. 
SECTION 4, RECOMMENDATIONS FOR THE DEVELOPMENT OF

AN ONGOING CONSUMER EVALUATION SYSTEM

The study described in this report was a one-time consumer feedback survey. It is hoped that this study may contribute to the development of an ongoing agency consumer evaluation system at the Family Court Service. As discussed in Chapter II, Section 1, such systems are probably not common among family court agencies.

Some possible advantages of an ongoing system are:

(1) the opportunity for consumers to continuously evaluate the agency

(2) the possibility for ongoing improvement of data collection instruments

(3) the opportunity to use continuousiy fresh data for the improvement of the service

(4) the ongoing involvement of staff in the examination of agency goals and objectives, and the use of evaluation data

Two possible disadvantages of an ongoing system are:

(1) the need for continuous commitment of staff time to evaluation, and the possibility of greater expense to the agency

(2) the possibility that more data will be produced than the agency can effectively use on an ongoing basis

Several recommendations might be made for the development of an ongoing consumer feedback system. As previously mentioned, the setting of criteria for program success would be a useful step for future evaluation. Established criteria would provide a means to compare consumer evaluation on an ongoing basis. 
For a system of continuous evaluation, small samples of clients contacted at short intervals might be more appropriate than a one-year sample. For example, a sample of former clients might be selected each week or month (perhaps every fifth client after case closing). At the end of six months, consumer feedback response could be tallied and compared to the data generated by this study without overburdening agency staff.

If the mail-out questionnaire method were retained, lack of staff time might dictate that the process of client contact be curtailed. Rather than two questionnaire mail-outs and telephone contacts, it might be feasible to use only one questionnaire mail-out. Assuming that this curtailment resulted in a lowered response rate, occasional research into the differences between respondents and nonrespondents might be advisable.

of course, many methods other than the mail-out questionnaire might be used to collect data for a consumer evaluation system. Some possibilities are in-person interviews, telephone interviews, questionnaires completed at the agency, and group discussions of consumer issues. A combination of two or more methods over a period of time might serve to maximize benefits and minimize the disadvantages of using one method only.

\section{SECTION 5, CONCLUSION}

The results of this study have been discussed in Chapter IV and the preceding sections of Chapter $V$. An analys is of study findings has been presented, as well as implications of study results, analys is of 
response rate, critique of the study, and recommendations for the development of an ongoing consumer evaluation system. It is hoped that the project purposes outlined in Chapter I have been fulfilled, particularly in the area of usefulness of this study to future evaluation efforts at the Family Court Service and other family court agencies.

The final step in the evaluation process is to determine the future course of action. This step has not been completed. Data from this study were presented to Family Court Service staff on a continuous basis in order to encourage discussion and avoid an information overload at the study's end. Client responses regarding satisfaction with counselor performance were presented individually and confidentially to each counselor. A staff workshop is planned with the purpose of examining possibilities for the use of project data in the counseling program. In addition, copies of this report or a summary of it will be made available to interested consumers, other parties involved with the agency, and interested individuals or agencies. 
SELECTED BIBLIOGRAPHY 


\section{SELECTED BIBLIOGRAPHY}

Brown, Emily H. "Divorce Counseling." In Treating Relationships, pp. 399-429. Edited by David 01son. Lake Mills, Iowa: Graphic Publishing Co., 1976.

Brown, Prudence. "Psychological Distress and Personal Growth among Women Coping with Marital Dissolution." Ph.D. dissertation, The University of Michigan, 1976.

Brown, Prudence, and Manela, Roger. "Client Satisfaction with Marital and Divorce Counseling." The Family Coordinator 26 (July 1977): 294-303.

Clackamas County Community Action Agency. "Clackamas County Profile Sheet." (Mimeographed.)

Clarkson, Quentin D.; Koroloff, Nancy; and Neuburger, Wayne. "The Evaluation Process." In Readings in Program Evaluation, pp. 1-11. Portland, Ore.: Regional Research Institute for Human Services, Portland State University, 1977.

Cochran, William G. Sampling Techniques. 2nd ed. New York: John Wiley \& Sons, Inc., 1953.

Dudley, James E.; Euler, J.; Njoroge, P.; and Streissguth, R. "Testing of a Design for Client Evaluation of a Conciliation Service." Masters practicum, Portland State University, 1972.

Elkin, Meyer. "Conciliation Courts: The Reintegration of Disintegrating Families." The Family Coordinator (January 1973):63-71.

"Short-Contact Counseling in a Conciliation Court." Social Casework 43 (April 1962):184-190.

Erdos, Paul L. Professional Mail Surveys. New York: McGraw-Hill Book Company, 1970 .

Furman, GTenn; Strickland, J.; Surkock, P., Jr.; and Toppenberg, L. "Clients' Perceptions of Conciliation Court Services." Masters research project, Arizona State University, 1971.

Giordano, Peggy C. "The Client's Perspective in Agency Evaluation." Social Work 22 (January 1977):34-39.

Goode, William J., and Hatt, Paul K. Methods in Social Research. New York: McGraw-Hill Book Company, Inc., 1952. 
Hagedorn, Homer J.; Beck, K. J.; Neubert, S. F.; and Werlin, S. H. A Working Manual of Simple Program Evaluation Techniques for Community Mental Health Centers. Washington, D.C.: Government Printing Office, 1976 .

Kresse1, Kenneth; Lopez-Morillas, M.; Weinglass, J.; and Deutsch, M. "Professional Intervention in Divorce: A Summary of the Views of Lawyers, Psychotherapists, and Clergy." (Mimeographed.)

McIntyre, Marguerite H.; Attkisson, C. Clifford; and Keller, Timothy W. "Components of Program Evaluation Capability in Community Mental Health Centers." In Resource Materials for Community Mental Health Program Evaluation, pp. 4-15. Edited by William A. Hargreaves, C. Clifford Attkisson, and James E. Sorenson. Washington, D.C.: Government Printing Office, 1977.

Nass, Gilbert D., and McIntire, Walter C. "Improving Response Rates to Mail Questionnaires in Family Life Research." The Family Coordinator 18 (July 1969):240-43.

Oppenheim, A. N. Questionnaire Design and Attitude Measurement. New York: Basic Books, Inc., 1966.

Powell, Barbara J.; Shaw, David; and O'Neal, Carol. "Client Evaluation of a Clinic's Services." Hospital and Community Psychiatry 22 (June 1971):45-46.

Rhodes, Clifton A., and Ihlow, Ginger. "Evaluation Findings on the Divorce Experience Program, October, 1975." Hennepin County Court Service, 1975. (Mimeographed.)

Rich, Bonnie A. "An Evaluation System for Highline-West Seattle Mental Health Center." Practicum, University of Washington, 1973.

Speer, David C., and Tapp, Jack C. "Evaluation of Mental Health Service Effectiveness: A 'Start Up' Model for Established Programs." American Journal of Orthopsychiatry 46 (Apri1 1976):217-28.

Suchman, Edward A. Evaluative Research: Principles and Practice in Public Service and Social Action Programs. New York: Russel7 Sage Foundation, 1967. 
APPENDIXES 
APPENDIX A

LIST OF INTERVIEW QUESTIONS

Client's Name Counselor's Name

We are evaluating Family Court Service to determine the helpfulness of the service and how we might improve it. A questionnaire will be mailed out to people who used Family Court Service. We are interested in getting your suggestions as to what questions we should ask on the questionnaire. This interview will be confidential; your answers will not be identified with your name.

1. How long should we wait after a client has been in before we send out an evaluation form? 3 mos. 6 mos. 9 mos. Other Why did you pick that time?

2. If you received a questionnaire in the mail that was two pages long, do you think you would fill it out and send it back? yes no no (If no, ask next question) Would it be too long? yes no (If no, ask next question) Why might you not fill it out and return it?

3. We are considering using a cover letter asking people's cooperation in returning the questionnaire signed by a judge. Would you be more inclined to return the questionnaire with that type of cover letter? yes no If no, why not? 
4. What subjects do you think should be covered on the questionnaire?

(If the person has a difficult time answering, use suggestions, such as fairness of the counselor, reception area, length of sessions, number of meetings, etc.) 


\section{APPENDIX B}

\section{CONSUMER EVALUATION OF CLACKAMAS COUNTY FAMILY COURT SERVICE}

DIRECTIONS: Please circle the letter next to your answer for each question.

1. a. Was your involvement with the Family Court Service helpful or not helpful?
(a) Was very unhelpfuT
(b) Was somewhat unhelpfur
(c) Helped somewhat
(d) Helped a great deal
(e) Not sure

b. In what ways was it helpful or unhelpful?

2. Did using the Family Court Service help you and your spouse or exspouse work together better as parents?
(a) Helped a great deal
(b) Helped somewhat
(c) Was somewhat unhelpful
(d) Was very unhelpful
(e) Not sure
(f) Does not apply

3. Do you think that you learned how to better handle your differences with your spouse or ex-spouse?
(a) Didn't learn at all
(b) Didn't learn much
(c) Learned some
(d) Learned a lot
(e) Not sure
(f) Does not apply 
4. Did you learn how to better help your children adjust to your family problems, separation, or divorce?
(a) Learned a lot
(b) Learned some
(c) Didn't learn much
(d) Didn't learn at all
(e) Not sure
(f) Does not apply

5. a. Were you satisfied with your counselor's assistance to you and your family?
(a) Very dissatisfied
(b) Dissatisfied in some ways
(c) Somewhat satisfied
(d) Very satisfied
(e) Not sure

b. In what ways were you satisfied or dissatisfied with your counselor's assistance?

6. What did you think of the number of sessions you attended at the Family Court Service?
(a) Too many
(b) About right
(c) Too few
(d) Not sure

7. We would like you to think back over your contacts with the Family Court Service. What suggestions do you have for changing or improving any part of the Agency? 
8. Was there any service not offered by this Agency that might have been of benefit to you or your family? If yes, what service?

Yes No

Thank you! Please return to: Family Court Service

704 Main Street, Suite 305

Oregon City, Oregon 97045 


\section{APPENDIX C}

COVER LETTER, FIRST QUESTIONNAIRE MAILING

Nolan Jones

Circuit Court of the State of Oregon

Director

Fifth Judicial District--Clackamas County

(503) $655-8415$ FAMILY COURT SERVICE

Suite 305, 704 Main Street, Oregon City, Oregon 97045

November 14, 1977

Dear

We need your help!

The Family Court Service wants to learn how to improve its services to families in this area. To accomplish this, we need your frank opinions regarding your experience with the agency.

It will take you only a short time to complete the enclosed questionnaire and return it in the stamped reply envelope. Each person who has used the agency during the past year is being asked to participate.

Your answers will be completely confidential and will be used only in combination with other responses. Your name will never be associated with your answers.

Please return the questionnaire at your earliest convenience. Your individual contribution to the survey is important and appreciated.

Thank you for your cooperation.

Sincerely,

Nolan Jones

$\mathrm{NJ} / \mathrm{dab}$

Director 
Nolan Jones Director
Circuit Court of the State of Oregon Fifth Judicial District--Clackamas County FAMILY COURT SERVICE Suite 305, 704 Main Street, Oregon City, Oregon 97045
(503) $655-8415$

November 30, 1977

Dear

You should have recently received a letter from the Family Court Service asking you to send us your frank opinions regarding your experience with this agency. Because of the importance of your participation in the survey, we are again requesting your cooperation. Your opinions are needed to help us learn how to improve our services to families in the future.

It will take you only a short time to complete the enclosed questionnaire and return it in the stamped reply envelope. Each person who has used the agency during the past year is being asked to participate.

Your answers will be completely confidential and will be used only in combination with other responses. Your name will never be associated with your answers.

Please return the questionnaire at your earliest convenience. Your individual contribution to the survey is important and appreciated.

Thank you for your help.

Sincerely,

$\mathrm{NJ} / \mathrm{dab}$

Nolan Jones

Director 


\section{APPENDIX E}

\section{PHONE INTERVIEW WITH NONRESPONDERS}

1. Is there a way we could have better contacted you than the mail-out questionnaire?

Personal interview?

Phone interview?

2. Were there particular reasons for you not sending back the questionnaire?

In the agency too long ago?

3. Was your involvement with FCS helpful or not helpful?

Why?

4. Was there anything about this service that should have been different or should be changed?

What?

5. Was there any service not offered by this Agency that might have been of benefit to. you or your family? yes no

If yes, what service? 